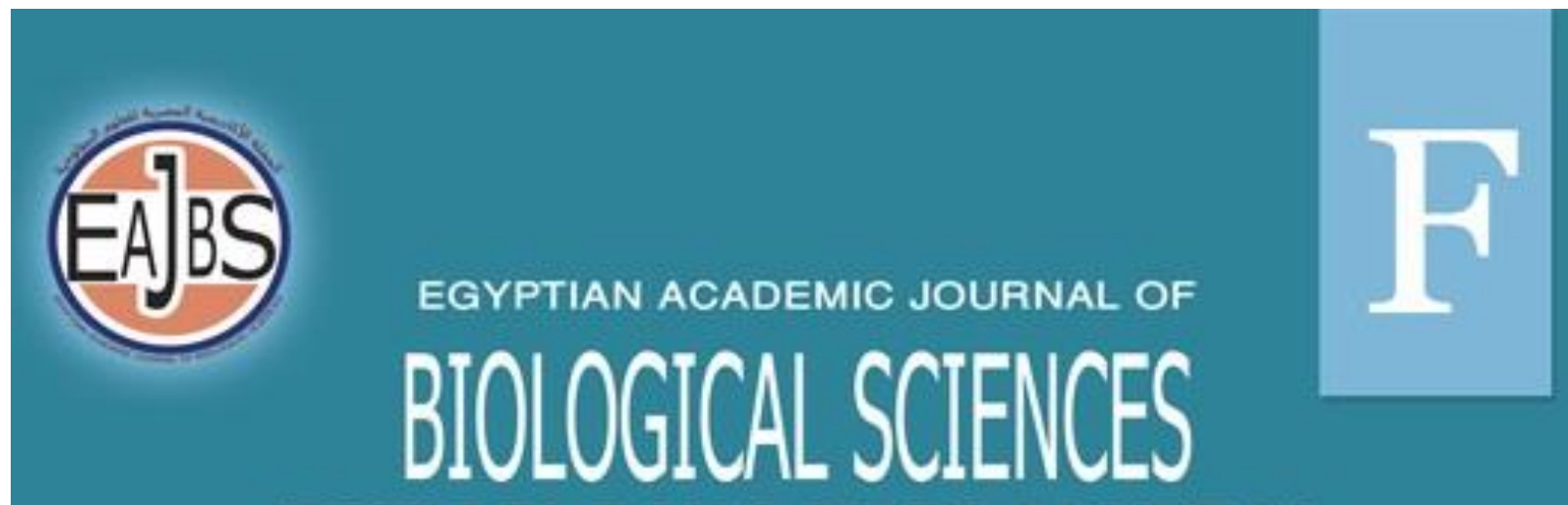

TOXICOLOGY \& PEST CONTROL

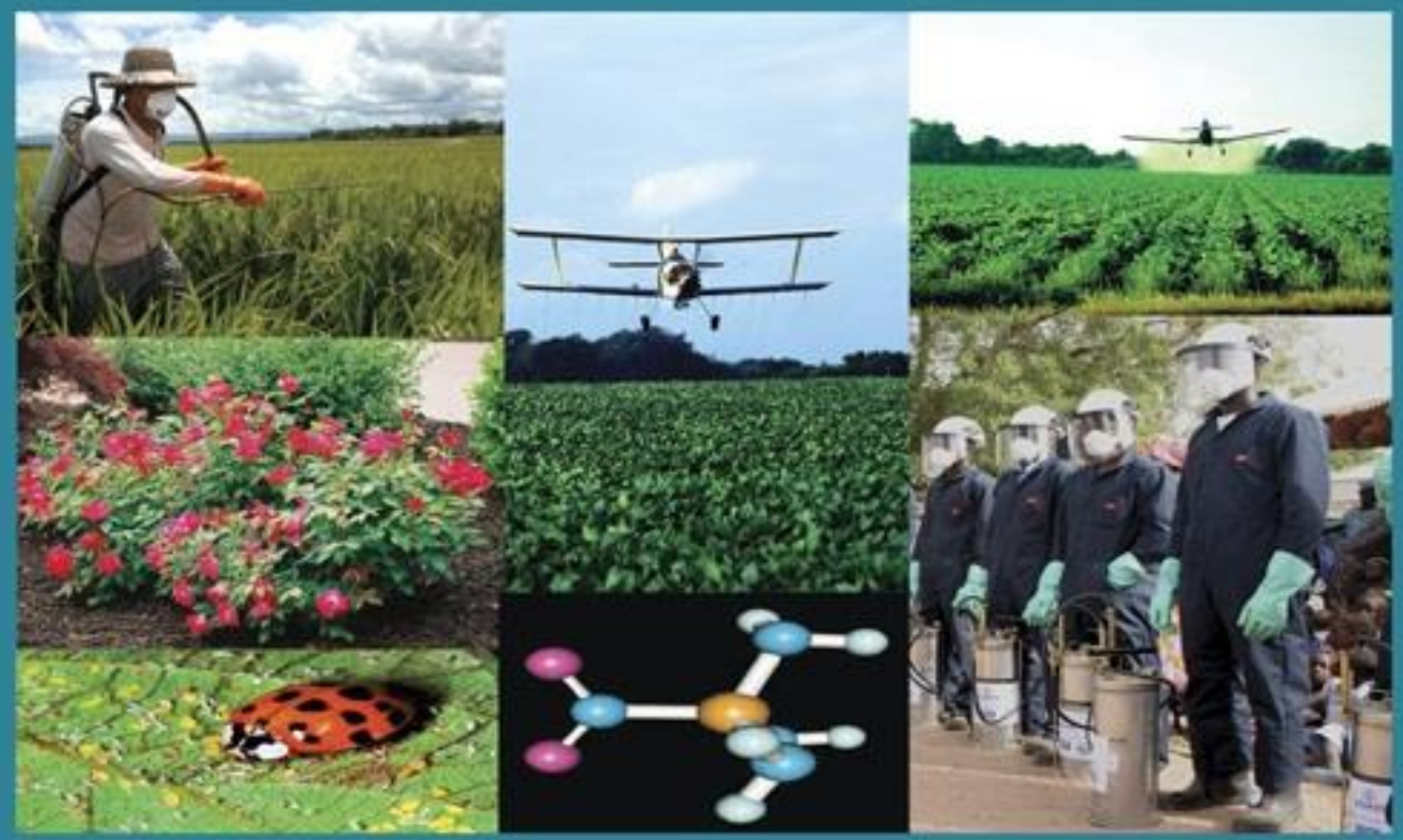

ISSN

2090-0791

WWW.EAJBS.EG.NET

Vol. 13 No. 1 (2021)

$\underline{\text { www.eajbs.eg.net }}$

Citation: Egypt. Acad. J. Biolog. Sci. (F.Toxicology \& Pest control) Vol.13(1)pp217-226(2021)

DOI: 10.21608/EAJBSF.2021.162947 
Egypt. Acad. J. Biolog. Sci., 13(1):217- 226 (2021)

Egyptian Academic Journal of Biological Sciences

F. Toxicology \& Pest Control

ISSN: 2090 - 0791

http://eajbsf.journals.ekb.eg/

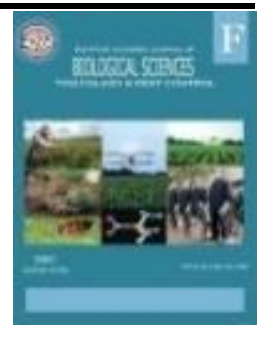

\title{
Toxicity of Nanosilica Particles on Eobania vermiculata and Their Effects on Biochemical Changes in Rats.
}

\author{
Ghada R. Mohamed, El-Shewy A.M. and Amany R. Morsy \\ Plant Protection Department, Faculty of Agriculture, Benha University, Egypt. \\ *E-Mail : amani.alzoheri@fagr.bu.edu.eg
}

\section{ARTICLE INFO}

Article History

Received: $15 / 1 / 2021$

Accepted: 21/3/2021

\section{Keywords:}

Organic, inorganic

nanosilica, Eobania

vermiculata, Rats,

hematological

parameters.

\section{ABSTRACT}

In the present study, organic and inorganic nanosilica were evaluated against the terrestrial snail Eobania vermiculata including mortality percentage, some life-cycle aspects studied included, also their effects on change in some biochemical parameters in albino Wistar rats under laboratory conditions.LC $\mathrm{C}_{50}$ values for organic and inorganic nanosilica treatments on the snail were $303.92 \mu \mathrm{g} / \mathrm{ml}$ and $6.282 \times 10^{4} \mu \mathrm{g} / \mathrm{g}$ after five and three days of treatment respectively. Data showed significant results against $E$. vermiculata life- cycle aspects and new generation where treatments caused a reduction of copulation, oviposition and larva stage percentages reached \{(50 and 25), (70.92 and 81.21) and (92.37 and 95.69) $\%$ \} for organic and inorganic nanosilica respectively. On rats, there were highly significant changes in hematological parameters in rats, as there were a very high significant decreased in WBCs, 4.70 and $4.87\left(10^{3} / \mu 1\right)$ when treated with organic and inorganic nanosilica respectively, compared with $10.80\left(10^{3} / \mu \mathrm{l}\right)$ in the control, a very high significant decreased in MCV by 73.63 and 74.0 (fl) respectively, compared with 91.30 (fl) in the control, a significant increase in RBCs treated with organic nano silica by 7.30 $\left(10^{6} / \mu \mathrm{l}\right)$ and a very high significant increase reached $7.90\left(10^{6} / \mu \mathrm{l}\right)$ in treated with inorganic nanosilica compared with $6.77\left(10^{6} / \mu 1\right)$ in the control. Also, a very high significance was detected in PLT treated with organic nanosilica reached $832.0\left(10^{3} / \mu 1\right)$ and a highly significant increase in treated with inorganic nanosilica by $811.07\left(10^{3} / \mu \mathrm{l}\right)$ compared with 478.0 $\left(10^{3} / \mu \mathrm{l}\right)$ in the control.

\section{INTRODUCTION}

Nanotechnology is a promising field of research that opens up in the present decade it is expected to give major impulses to technical innovations in a variety of industrial and agriculture sectors in the future. The potential uses and benefits of nanotechnology are enormous. These include agricultural productivity enhancement for efficient dosage of water and fertilizer. The atom-by-atom arrangement allows the manipulation of nanoparticles thus influencing their size, shape and orientation for reaction with the targeted tissues (Bhattacharyya et al., 2010). Nanoparticles exhibit different physical strength, chemical reactivity, electrical conductance and magnetic properties (Nykypanchuk et al., 2008). Thus, nanotechnology will revolutionize agriculture including pest management in the near future. Over the next two decades, the green revolution would be accelerated by 
means of nanotechnology. A few years ago; the uses of synthetic pesticides in modern agriculture production promoted the widespread of environmental contamination, toxicity to human food as well as the resistance of targeted pest was developed and hazards to human health occurred (Pretty et al., 2009). Hence, controlling pests required a modern technology of fewer hazards to human health with no residues in their food and less resistance to the pest.

Land snails are one of the most important invertebrate pests that spread in the world. In recent years, these pests spread widely in many Arab countries, especially Egypt. The importance of these gastropods pests is that they can feed on all parts of many plant species without discrimination (Al-Akraa and Mohammed, 2015 and Gazzy et al., 2019). Besides, these animals transmit a number of bacterial, fungal and viral diseases to infected plants, through a mucous substance secreted during feeding and movement, thus increasing the damage to plants. Some of these pests have a very important role in transmitting some worms to humans and other animals (Lu et al., 2011). Many control methods have been used in recent years to reduce the dangers of these pests (Sharaf et al 2015). Using nanomaterials became one of the modern and new technologies to combat the different pests quickly and effectively (Safaa et al., 2015).

The present study is a trial to characterize the selected organic and inorganic nanosilica particles using a transmission electron microscope (TEM) followed by an evaluation of the molluscicidal efficacy of these particles against Eobania vermiculata snail under laboratory conditions. Also, the effect of these materials on rats was studied.

\section{MATERIALS AND METHODS}

\section{Tested Materials:}

- organic and inorganic nanosilica (Sio2)

- Size (TEM):100nm

- Purity: $99 \%$

- Form: liquid for organic and powder for inorganic nanosilica.

- Source: purchased from Nano Way Company, Egypt.

- Size and shape characterization of nanoparticles.

The nanoparticles sizes were analyzed by the Transmission Electron Microscope of the Nanotechnology and Advanced Material Central Lab, (NAMCL), National Research Center (NRC). Gun type: LaB6 Gun.

Model: Tecnai G20, Super twin, double tilt. Applied voltage: $200 \mathrm{Kv}$.

Preparation of Eobania vermiculata Land Snail in The Laboratory:

Adult of the snail Eobania vermiculata individuals were brought from multiple plants to the Agricultural Animal Laboratory of the Faculty of Agriculture, Benha University. The animals were thoroughly washed with water to remove traces of mud and dirt, and left until the animals moved to distinguish the injured from the healthy individuals. The best healthy individuals were selected from almost the same size and placed in plastic cages feeding on fresh lettuce plants while covering the cages with a light perforated cloth to help the animals breathe and prevent the individuals from escaping (Mohammed 2018). The animals were starved for a week before the start of the experiments.

\section{Toxicity Test Against E. vermiculata Land Snail:}

Serial concentrations of tested materials were prepared at 1000, 800, 600, 400 and $200 \mu \mathrm{g} / \mathrm{ml}$ for organic nanosilica and $32 \times 10^{4}, 16 \times 10^{4}, 8 \times 10^{4}, 4 \times 10^{4}, 2 \times 10^{4} \mu \mathrm{g} / \mathrm{g}$ for inorganic nanosilica, three replicates were used for each concentration, each of five adults. Fresh lettuce leaves were mixed with the different concentrations for two tested nanomaterials and placed inside the replicates with E. vermiculata individuals and covered 
to prevent escape. Mortalities were recorded after 1, 2, 3, 5, 7and 10 days of treatment the recorded mortalities were corrected according to Abbott's formula (1925).

Aspects of Eobania vermiculata Life-Cycle:

Lettuce leaves were mixed with $\overline{L C}_{50}$ of each of the tested nanomaterials and submitted for E. vermiculata adults to clarification the effect of these materials on some lifecycle aspects. Four replicates for each material and control. Two snail adults for each replicate and follow-up took place daily. After copulation, each snail was translocated to a separate cup containing wet clay and watched until eggs laying (Mohammed 2004). Copulation percentage, copulation period, pre-laying eggs period, egg-laying percentage, the average total number of laid eggs, percentage of eggs in clutches form, the average number of eggs in each clutch, an average of clutch depth, percentage of eggs in solitary form, an average of eggs weight, average of egg diameter, incubation period, hatching percentage and the average number of alive larvae were estimated. Finally, the reduction percentages were calculated for copulation, oviposition and larva stage. Hatchability percentage was calculated according to Mohammed (2004) but the inhibition of copulation, oviposition and larva stage were calculated according to Zhang et al., (2013)

\section{Biosafety Experiment:}

Twenty-seven males of albino Wistar rats were obtained from the Faculty of Veterinary Medicine, Benha University. Rats were clinically healthy. Those were acclimatized one week before the experiment, 80 - $100 \mathrm{gm}$ weight/rat. Rats were randomly assigned to three groups; the first group fed on grain mixed with organic nanosilica, the second group fed on grain mixed with inorganic nanosilica and a third group was fed on untreated grain as control. Three replicates were tested out for each group. The samples of blood were taken after ten days of treatment.

Analysis of Hematology and Biochemical Parameters:

Blood samples were taken after ten days of treatments directed from heart rats. The samples were centrifuged at $3000 \mathrm{rpm}$ for 15 minutes. The serum was collected and kept in the freezer at $-20 \mathrm{C}^{0}$. Alanine Transaminase (ALT), Alkaline Phosphatase (ALP), Creatinine (CREA), White Blood cells (WBC), Red Blood cells (RBC), Hemoglobin (HGB), Hematocrit (HCT), Platelets (PLT), Mean Corpuscular Hemoglobin (MCH), Mean Corpuscular Volume (MCV) and Mean Corpuscular Hemoglobin Concentration (MCHC) according to Raoofi et al., (2016).

\section{Statistical Analysis:}

The obtained mortality data were subjected to Probit analysis (Finney, 1971), using a computer Program of Noack and Reichmuth (1978).

The statistical analysis was carried out using one-way ANOVA using SPSS, ver. 25 (IBM Corp. Released 2013). Data were treated as a complete randomization design according to Steel et al., (1997). The significance level was set at $<0.05$.

\section{RESULTS AND DISCUSSION}

\section{Characterization of Organic and Inorganic Nanosilica:}

The characterization and morphology of organic and inorganic nanosilica particles visualized using transmission electron microscopy (TEM). The particles appeared spherical and round in shape. The average size of the nanoparticles of organic and inorganic nanosilica were 150 and $100 \mathrm{~nm}$ respectively, (Figs., 1 and 2). 


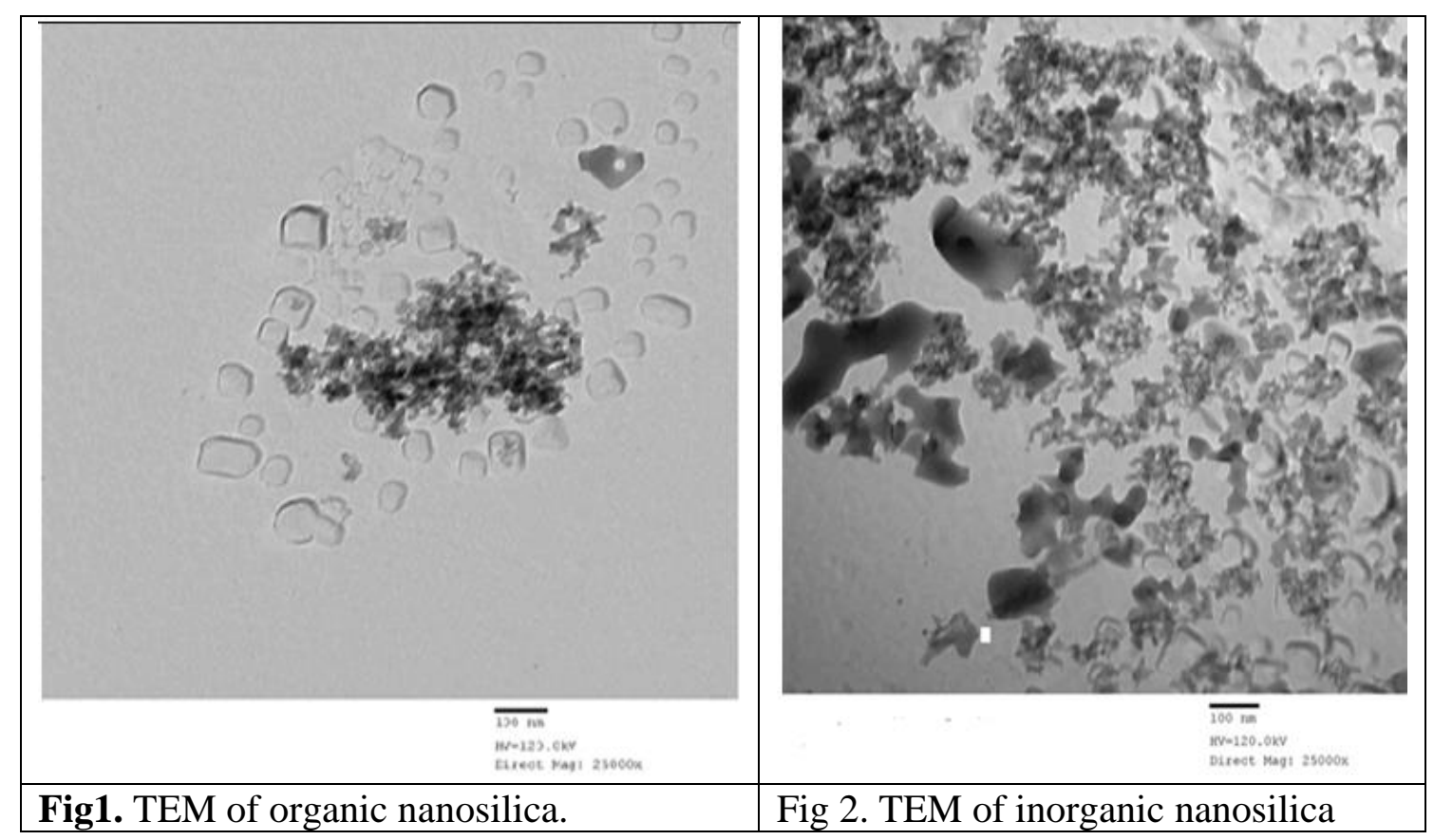

\section{Toxicities of Organic and Inorganic Nanosilica on E. vermiculata:}

The $\mathrm{LC}_{\mathbf{5 0}}$ values for organic and inorganic nanosilica after five and three days, respectively on $E$. vermiculata were $303.92 \mu \mathrm{g} / \mathrm{ml}$ and $6.282 \times 10^{4} \mu \mathrm{g} / \mathrm{g}$, respectively (Table,1). The correspondent values of LC90 were much lower in inorganic nanosilica treatment $\left(34.909 \times 10^{4} \mu \mathrm{g} / \mathrm{g}\right)$ than that of the organic nanosilica $(919.78 \mu \mathrm{g} / \mathrm{ml})$, respectively.

These results agree with those of Fahmy et al., (2014) found that the LC50 and LC90 of zinc oxide nanoparticles against the snail Biomphalaria alexandrina were 145 and 2700 $\mu \mathrm{g} / \mathrm{ml}$. It was reported that zinc oxide NPs showed molluscicidal activity against this snail induce malondialdehyde and nitric oxide with decreasing of glutathione and glutathione $\mathrm{S}$ transferase levels in hemolymph and soft tissues so the death of this snail.

Table1. $\mathrm{LC}_{50}$ and $\mathrm{LC}_{90}$ values of organic and inorganic nanosilica on E. vermiculata.

\begin{tabular}{|c|c|c|c|}
\hline Treatments & $\begin{array}{c}\mathbf{L C}_{\mathbf{5 0}} \\
\text { (lower-upper) }\end{array}$ & $\begin{array}{c}\text { LC } \\
\text { (lower }- \text { upper) }\end{array}$ & SLOP \pm SE \\
\hline Organic nonosilica & $\begin{array}{c}303.92 \\
(226.2-369.8)\end{array}$ & $\begin{array}{c}919.78 \\
(728.5-1362.9)\end{array}$ & $2.665 \pm 0.97$ \\
\hline Inorganic nanosilica & $\begin{array}{c}6.282 \times 10^{4} \\
\left(2.901 \times 10^{4}-11.45 \times 10^{4}\right)\end{array}$ & $\begin{array}{c}34.909 \times 10^{4} \\
\left(16.9 \times 10^{4}-39.77 \times 10^{4}\right)\end{array}$ & $1.721 \pm 0.99$ \\
\hline
\end{tabular}

$\mathrm{SE}=$ standerd error of the mortality regression line.

Nanosilica is one of the most spreading materials on earth; it possesses a highly adhesive property to the cell membrane, so, it affects the membrane structures. Furthermore, this nanosilica can be absorbed by phospholipid present in cuticle of the larval instar by physisorption and lysis so cause death (Barik et al., 2008 and Tiwari and Behari, 2009).

Hydrophilic NSP was selected and identified by TEM to appear spherical in shape with a size range of $80 \mathrm{~nm}$ in diameter. This size proved that they are able to adhere and absorb by the surface of target agents inducing mortality (Barik et al., 2008 and Salunkhe et al., 2011).

The ability of the tested NSP to cause mortalities in snails may be related to this suggested mode of actions (Barik et al., 2008 and Barik et al., 2012) as NSP can be absorbed by phospholipid found in the cuticle of larval instar by physisorption and lysis so cause death 
to larval insects (Barik et al., 2008 and Barik et al., 2012). For this reason; their effect was high as the exposed tegument is thin. The LC $\mathbf{5 0}_{\mathbf{5 0}}$ and $\mathrm{LC}_{\mathbf{9 0}}$ of hydrophilic nanosilica to Biomphalaria alexandrina were $590 \mathrm{ppm} / 6 \mathrm{~h}$ and $980 \mathrm{ppm} / 48 \mathrm{~h}$, respectively (Attia et al., 2017).

\section{Effect of Organic and Inorganic Nanosilica on $E$. vermiculata Life-Cycle Aspects:}

Data in table (2) indicated that the two tested materials had a high effect on many aspects of life for E. vermiculata. At the beginning, no significant difference was found between these materials and control in the occurrence of copulation, despite the low mating rate of 50, 75 and $100 \%$ for organic nanosilica, inorganic nanosilica and control, respectively. Reduction Percentage of copulation reached to50 and $25 \%$ for organic nanosilica, inorganic nanosilica, respectively. On the other hand, there was a highly significant difference in the copulation period spent by snails in case of inorganic nanosilica were increased to $16.13 \mathrm{hr}$. versus 12.66 and $10.95 \mathrm{hr}$. for inorganic nanosilica and control, respectively. Besides the period E. vermiculata spent before laying of eggs were high and very high significant between the two tested materials and control, respectively showing $14.33,15.25$ and 11.38 days for organic nanosilica, inorganic nanosilica and control, respectively. The rates of laying eggs were no significant between organic nanosilica, inorganic nanosilica and control being 75, 66.67 and $100 \%$, respectively but there was a clear decrease in the average total number of eggs laid by treated individuals of $E$. vermiculata compared to untreated ones, especially in case of inorganic nanosilica article where a highly significant difference appeared with mean of 28 eggs only, while untreated individuals were able to lay 111.75 eggs on average. Thus, it appeared that there was clear inhibition in oviposition of treated E. vermiculata individuals that reached 70.92 and $81.21 \%$ after treatment by organic and inorganic nanosilica respectively. A significant difference was confirmed for the percentage of eggs laid in the clutch form in the case of inorganic nanosilica with $25 \%$ only, while no significant difference occurred between organic nanosilica and control. In terms of the number of eggs per clutch. It was also evident from results that high significant differences occurred between the two tested nano materials and control, and it was very highly significant for inorganic nanosilica with means of 45.50, 37 and 69.67 eggs/clutch for organic nanosilica, inorganic nanosilica and control respectively. Tested materials also showed a clear effect on the depth of laid eggs in the soil. In this respect, data showed very high significant differences between treated and untreated individuals, where the depth of hole decreased reached $3.80 \mathrm{~cm}$ when individuals were treated by organic nanosilica compared to control $5.57 \mathrm{~cm}$. While individuals treated by inorganic nonosilica couldn't burrow in the soil. Regarding the percentage of eggs laid in solitary form, it increased to $75 \%$ when E. vermiculata individuals were treated with inorganic nanosilica. About the weight and diameter of eggs, a highly significant difference was detected, when individuals were treated with inorganic nanosilica, the mean weight of 10 eggs decreased to $0.31 \mathrm{~g}$ and the average egg diameter decreased to $3.08 \mathrm{~mm}$. Besides, the incubation period of eggs was longer in case of individuals treated with organic and inorganic nanosilica than individuals in control, being 16.67, 18.25 and 13.88 days respectively, thus indicating high and very high significant differences between transactions and control. Concerning eggs hatching percentage and the average number of larvae that survived after hatching, the results showed that there was a very high significant difference between untreated and treated E. vermiculata individuals, where hatchability rate and mean of the total number of alive larvae decreased from $92.19 \%$ and 45.88 larvae in control to 53.27 and $46.30 \%$, and 9.33 and 4 larvae for organic and inorganic nanosilica, respectively resulting in a decrease in population of a new generation of $E$. vermiculata due to inhibition in larva percentage that increased to 92.37 and $95.64 \%$ when snails were treated with the same two tested materials, respectively. 
Table 2: Effect of organic and inorganic nanosilica on some aspects of Eobania vermiculata life- cycle under laboratory conditions.

\begin{tabular}{|c|c|c|c|c|c|c|c|c|c|c|c|c|c|c|c|c|c|}
\hline \multirow[b]{2}{*}{ Treatments } & \multicolumn{17}{|c|}{ Some of life cycle aspects of $E$. vermiculata land snail } \\
\hline & $\begin{array}{l}\text { CO } \\
(\%)\end{array}$ & $\begin{array}{l}\text { P of } \\
\text { CO } \\
\text { (hr.) }\end{array}$ & $\begin{array}{l}\text { PBLE } \\
\text { (day) }\end{array}$ & $\begin{array}{l}\text { LE } \\
(\%)\end{array}$ & $\begin{array}{c}\text { Mean } \\
\text { of } \\
\text { TNE }\end{array}$ & $\begin{array}{c}\mathrm{E}(\mathrm{CH}) \\
(\%)\end{array}$ & $\begin{array}{c}\text { Mean } \\
\text { of } \\
\text { E/CH }\end{array}$ & $\begin{array}{c}\text { Mean } \\
\text { of } \\
\text { DCH } \\
\text { (cm) }\end{array}$ & $\begin{array}{l}\mathbf{E}(\mathbf{S}) \\
(\%)\end{array}$ & $\begin{array}{l}\text { Mean of } \\
10 \mathrm{EW} \\
\text { (g) }\end{array}$ & $\begin{array}{c}\text { Mean } \\
\text { of ED } \\
(\mathrm{mm})\end{array}$ & $\begin{array}{l}\text { Mean } \\
\text { of IP } \\
\text { (day) }\end{array}$ & $\begin{array}{l}\mathrm{HE} \\
(\%)\end{array}$ & $\begin{array}{c}\text { Mean } \\
\text { of } \\
\text { TNLL }\end{array}$ & $\begin{array}{l}\text { I. C } \\
(\%)\end{array}$ & $\begin{array}{l}1.0 \\
(\%)\end{array}$ & $\begin{array}{l}\text { I. L } \\
(\%)\end{array}$ \\
\hline $\begin{array}{c}\text { Organic } \\
\text { nanosilica }\end{array}$ & $\begin{array}{c}\mathbf{5 0 . 0 0 \pm} \\
28.87\end{array}$ & $\begin{array}{c}12.66 \pm \\
2.55\end{array}$ & $\begin{array}{l}14.33 \pm \\
0.67^{\star *}\end{array}$ & $\begin{array}{c}75.00 \pm \\
25.00\end{array}$ & $\begin{array}{l}65.00 \pm \\
24.00\end{array}$ & $\begin{array}{c}66.70 \pm \\
0.00\end{array}$ & $\begin{array}{l}45.50 \pm \\
4.50^{\star *}\end{array}$ & $\begin{array}{c}3.80 \pm \\
0.70^{* * *}\end{array}$ & $\begin{array}{c}\mathbf{3 3 . 3 5 \pm} \\
\mathbf{0 . 3 0}\end{array}$ & $\begin{array}{c}0.46 \pm \\
0.04\end{array}$ & $\begin{array}{l}3.47 \pm \\
0.49 *\end{array}$ & $\begin{array}{l}16.67 \pm \\
0.88^{* *}\end{array}$ & \begin{tabular}{|l}
$53.27 \pm$ \\
$4.00^{* * * *}$
\end{tabular} & \begin{tabular}{|c|}
$9.33 \pm$ \\
$1.20^{* * * *}$
\end{tabular} & 50 & 70.92 & 92.37 \\
\hline $\begin{array}{l}\text { Inorganic } \\
\text { nanosilica }\end{array}$ & $\begin{array}{c}75.00 \pm \\
25.00\end{array}$ & $\begin{array}{l}16.13 \pm \\
1.02^{* *}\end{array}$ & $\begin{array}{c}15.25 \pm \\
0.48^{* * *}\end{array}$ & $\begin{array}{c}66.67 \pm \\
16.67\end{array}$ & $\begin{array}{l}28.00 \pm \\
10.60^{* *}\end{array}$ & $\begin{array}{c}25.00 \pm \\
0.00^{*}\end{array}$ & $\begin{array}{c}37.00 \pm \\
0.00^{* * *}\end{array}$ & $\begin{array}{c}0.00 \pm \\
0.00^{* \star * *}\end{array}$ & $\begin{array}{c}75.00 \pm \\
0.00^{*}\end{array}$ & $\begin{array}{c}0.31 \pm \\
0.03^{* *}\end{array}$ & $\begin{array}{c}3.08 \pm \\
0.05^{* *}\end{array}$ & $\begin{array}{l}18.25 \pm \\
0.63^{* * *}\end{array}$ & $\begin{array}{c}46.30 \pm \\
3.78^{* * *}\end{array}$ & \begin{tabular}{|c|}
$4.00 \pm$ \\
$2.38 * * *$
\end{tabular} & 25 & 81.21 & 95.64 \\
\hline Control & $\begin{array}{c}100.00 \pm \\
0.00\end{array}$ & $\begin{array}{c}10.95 \pm \\
1.40\end{array}$ & $\begin{array}{c}11.38 \pm \\
0.38\end{array}$ & $\begin{array}{c}100.00 \pm \\
0.00\end{array}$ & $\begin{array}{c}111.75 \pm \\
19.72\end{array}$ & $\begin{array}{c}75.00 \pm \\
14.43\end{array}$ & $\begin{array}{c}69.67 \pm \\
4.42\end{array}$ & $\begin{array}{c}5.57 \pm \\
0.24\end{array}$ & $\begin{array}{c}25.00 \pm \\
14.43\end{array}$ & $\begin{array}{c}0.55 \pm \\
0.05\end{array}$ & $\begin{array}{l}4.08 \pm \\
0.16\end{array}$ & $\begin{array}{c}13.88 \pm \\
0.64\end{array}$ & $\begin{array}{c}92.19 \pm \\
2.18\end{array}$ & $\begin{array}{c}45.88 \pm \\
8.21\end{array}$ & - & - & - \\
\hline
\end{tabular}

$\mathrm{N}$ on significant $(\mathrm{P}>0.05) \quad *$ : Significant $(\mathrm{P}<0.05) \quad * *$ : High significant $(\mathrm{P}<0.01) \quad * * *$ : Very high significant $(\mathrm{P}<0.001)$

CO: Copulation (\%)

LE: The Laying of Eggs

$\mathrm{E} / \mathrm{CH}$ : Eggs in each Clutch

EW: Egg Weight (g)

HE: Hatching eggs (\%)

I. C: Inhibition of Copulation (\%)

\author{
P of CO: Period of Copulation (hours) \\ TNE: The Total Number of Eggs \\ DCH: Depth of Clutch $(\mathrm{cm})$ \\ ES: Egg Diameter \\ TNLL: Total Number of Living Larva stage \\ I. O: Inhibition of Oviposition (\%)
}

PBLE: The Period before Eggs laying (days). E (CH): Eggs laid Clutch (\%) E (S): Eggs laid Solitary (\%) IP: Incubation Period

I. L: Inhibition of Larva stage (\%)

Generally, the formerly explained results confirmed that organic and inorganic nanosilica had a clear and significant effect on many aspects of $E$. vermiculata life-cycle, especially in case of inorganic nanosilica which had the greatest effect. Finally, using these materials in E. vermiculata control led to a reduction in the copulation and fertility of snail, where a small number of eggs were laid as well as the hatchability rate of the resulting eggs was inhibited. This, in turn, ultimately reduced the number of larvae in the next generation. These results agree with Sana et al., (2016) where used iron oxide powder (Fe2O3) nanoparticles against Helix aspersa land snail greatly significantly, affected the life-cycle of the terrestrial snail, as the treatments resulted in the appearance of deformation of the laid eggs and there was also a significant decrease in the percentage of hatching eggs. Silver nanoparticles (AgNPs) were used to control Eobania vermiculata land snail by Safaa et al., (2015). Their results showed that these materials affected the snail activity in the soil. Also, silver nanoparticles (AgNPs) showed great effectiveness on the life cycle of the gastropod freshwater snail Physa acuta by Sandra et al., (2017).

\section{Hematological Parameters in Control and Tested Materials on Rates:}

The results of the present study showed that the change in hematologic parameters in serum concentrations of WBCs, HGb, RBCs, MCV, HCT, MCHC and PLT in rat's animals treated with organic nanosilica and inorganic nanosilica, Table 3.

Data showed that there was no significant effect in $\mathrm{HGb} \%$ of rats when treated with organic and inorganic nanosilica the values retched to 15.43 and $15.70 \%$ respectively, compared with $15.30 \%$ in the control. While there was a very high significant decrease in WBCs in rats' animals, the values reached 4.70 and $4.87\left(10^{3} / \mu 1\right)$ when treated with organic and inorganic nanosilica respectively, compared with $10.80\left(10^{3} / \mu 1\right)$ in the control. Also, rats treated with organic and inorganic nanosilica showed a very high significantly decreased in MCV by 73.63 and 74.0 (fl) respectively, compared to 91.30 (fl) in the control treatments. In the same trend, a very high significant decrease in HCT \% treated with organic and inorganic nanosilica reached 48.63 and 46.30 respectively, compared to $50.30 \%$ in the control. On contrary, there was a significant increase in RBCs treated with organic nanosilica by $7.30\left(10^{6} / \mu \mathrm{l}\right)$ and a very high significant increase reached $7.90\left(10^{6} / \mu \mathrm{l}\right)$ in treated rats with inorganic nanosilica compared with $6.77\left(10^{6} / \mu 1\right)$ in the control. Also, a very high significance showed in PLT of treated rats with organic nanosilica reached $832.0\left(10^{3} / \mu \mathrm{l}\right)$ and a highly significant increase in rats treated with in organic nanosilica by $811.07\left(10^{3} / \mu 1\right)$ compared with $478.0\left(10^{3} / \mu 1\right)$ in the control. 
Table 3: Hematological parameters in rats treated by tested materials.

\begin{tabular}{|c|c|c|c|}
\hline Parameters & Control & Organic Nanosilica & Inorganic Nanosilica \\
\hline HGb (\%) & $15.30 \pm 0.17$ & $15.43 \pm 0.03$ & $15.70 \pm 0.12$ \\
\hline WBCs $\left(10^{3} / \mu \mathrm{l}\right)$ & $10.80 \pm 0.06$ & $4.70 \pm 0.12 * * *$ & $4.87 \pm 0.03 * * *$ \\
\hline MCV (fl) & $91.30 \pm 0.12$ & $73.63 \pm 0.20 * * *$ & $74.00 \pm 0.00 * * *$ \\
\hline HCT (\%) & $50.30 \pm 0.12$ & $48.63 \pm 0.03 * * *$ & $46.30 \pm 0.06 * * *$ \\
\hline RBCs $\left(10^{6} / \mu \mathrm{l}\right)$ & $6.77 \pm 0.07$ & $7.30 \pm 0.17 *$ & $7.90 \pm 0.06 * * *$ \\
\hline PLT $\left(10^{3} / \mu \mathrm{l}\right)$ & $478.00 \pm 1.73$ & $832.00 \pm 1.15 * * *$ & $811.07 \pm 0.03 * *$ \\
\hline MCH (Pg) & $33.60 \pm 0.06$ & $32.14 \pm 0.01 * * *$ & $36.31 \pm 0.01 * * *$ \\
\hline MCHC (\%) & $46.40 \pm 0.23$ & $44.23 \pm 0.15 * * *$ & $47.03 \pm 0.02 *$ \\
\hline
\end{tabular}

Nonsignificant $(\mathrm{P}>0.05) \quad *$ : Significant $(\mathrm{P}<0.05) \quad * *$ : High significant $(\mathrm{P}<0.01) \quad * * *$ : Very high significant $(\mathrm{P}<0.001)$

WBC: white blood cell count, HGb: hemoglobin, RBC: red blood cell count, HCT: Platelets, PLT: Mean Corpusclarn Hemoglobin, MCH: Mean Corpusclarn Volume, MCHC: Mean Corpusclarn Hemoglobin Concentration, MCV: mean cell volume.

On the other hand, rats treated with organic and inorganic nanosilica showed variable effects in the $\mathrm{MCH}(\mathrm{Pg})$ and $\mathrm{MCHC} \%$.

$\mathrm{MCH}$ recorded a very high decrease by $32.14(\mathrm{Pg})$ treated with organic nanosilica, but inorganic nanosilica treatment showed a significant increase by 36.31 (Pg) compared with $33.60(\mathrm{Pg})$ in the control. The same effect occurred in MCHC \% showed a very high significant decrease reached to $44.23 \%$ in case of organic nanosilica application and showed a significant increase reached to $47.03 \%$ for treatment with inorganic nanosilica compared with $46.40 \%$ in the control (Table,3).

\section{Biochemical Parameters in Control and Tested Materials on Rats:}

The effects of tested compounds on serum biochemical analysis were recorded in Table 4 . There were a very high significant decreased in creatinine $(\mathrm{mg} / \mathrm{dl})$ reached to 0.4 and $0.42(\mathrm{mg} / \mathrm{dl})$ when treated with Organic Nano Silica and Inorganic Nano Silica respectively, compared with 0.56 (mg/dl) in the control. Also, ALP (U/L) showed a very high significant decreased when treated with Organic Nano Silica and Inorganic Nano Silica by 3.52 and 3.7 (U/L) respectively, compared with 4.96 (U/L) in the control.

On the other hand, the effect on ALT (U/L) recorded a very high significant increase when treatment took place with organic or inorganic sanosilica the values reached 120.01 and 121.07 (U/L) respectively, compared with 25.07 (U/L) in case of the control, (Table,4).

The obtained results agree with Song et al., (2009) who stated that exposure to nanosilica, resulted in a downward trend in WBC, neutrophils, and monocyte counts in the blood of rats, as well as a significant fall in neutrophils. In addition, compared to control, ALT and LDH presented an upward trend in exposure groups, thus indicating the existence of liver damage after exposures. The present results indicate that nanosilica materials have similar toxicity, which is consistent with the increase of ALT.

The liver is an important organ for detoxification in the body and plays a vital role in the metabolism of nanomaterials. It has been shown that tail vein injection by nanosilica resulted in a significant accumulation of nanoparticles in the liver and resulted in liver injury (Lu et al., 2011 and Xie et al., 2010). Also, Oxidative stress in mice livers was notably prevalent after exposure to nanosilica, resulting in hepatic injury (Steel et al., 1997). The results of serum ALT and LDH levels in the exposed animals in the present study supported liver-damaging by silica-containing nanoparticles (So et al., 2008 and Ye et al., 2010). 
Table 4: biochemical parameters in control and tested materials:

\begin{tabular}{|l|c|c|c|}
\hline Parameters & Control & $\begin{array}{c}\text { Organic Nano } \\
\text { Silica }\end{array}$ & $\begin{array}{c}\text { Inorganic Nano } \\
\text { Silica }\end{array}$ \\
\hline CREAT (mg/dl) & $\mathbf{0 . 5 6} \pm \mathbf{0 . 0 1}$ & $\mathbf{0 . 4 1} \pm \mathbf{0 . 0 1} * * *$ & $\mathbf{0 . 4 2} \pm \mathbf{0 . 0 1} * * *$ \\
\hline ALP (U/L) & $\mathbf{4 . 9 6} \pm \mathbf{0 . 0 2}$ & $\mathbf{3 . 5 2} \pm \mathbf{0 . 0 1} * * *$ & $\mathbf{3 . 7 0} \pm \mathbf{0 . 1 2} * * *$ \\
\hline ALT (U/L) & $\mathbf{2 5 . 0 7} \pm \mathbf{0 . 0 7}$ & $\mathbf{1 2 0 . 0 1} \pm \mathbf{0 . 0 1} * * *$ & $\mathbf{1 2 1 . 0 7} \pm \mathbf{0 . 0 2} * * *$ \\
\hline
\end{tabular}
$\begin{aligned} & \text { Non-significant }(\mathrm{P}>0.05) \\
& \text { high significant }(\mathrm{P}<0.001)\end{aligned}$
ALT: Significant $(\mathrm{P}<0.05) \quad * *$ High significant $(\mathrm{P}<0.01) \quad * * *$ Very

\section{REFERENCES}

Abbott, W.S., 1925. A method of computing the effectiveness of an insecticide. Journal. Economic. Entomology; 265-266.

Al-Akraa, T.M.M. and Mohammed, Gh. R. 2015. Toxicity and biochemical studies of some pesticides against small sand snail Helicella vestalis (Pfeiffer). Annals. of Agricultural. Sciences, Moshtohor, 53(3): 467-472.

Attia M. M, Soliman SM, Khalf MA. 2017. Hydrophilic nanosilica as a new larvicidal and molluscicidal agent for controlling of major infectious diseases in Egypt. Veterinary World, 10(9): 1046-1051.

Barik, T.K., Sahu, B. and Swain, V. 2008. Nanosilica from medicine to pest control. Parasitology Research, 103(2): 253-258.

Barik, T.K., Kamaraju, R. and Gowswami, R. 2012. Silica nanoparticle: A potential new insecticide for mosquito vector control. Parasitology. Research, 111: 1075-1083.

Bhattacharyya A, Bhaumik A, Usha Rani P, Mandal S, Timothy TE. 2010. Nano-particles A recent approach to insect pest control. African Journal of Biotechnology, 9(24): 3489-3493.

Dosis-Werten eines Wirkstoffes au's empirisch Dosis- wirkungs- Daten Mitt. Boil Bundesanstalt fur Land Forstwirtsch. Berlin Dahlem, Haft, 185: 1-49.

Fahmy, S.R., Abdel-Ghaffar, F., Bakry, F.A. and Sayed, D.A. 2014. Ecotoxicological effect of sublethal exposure to zinc oxide nanoparticles on freshwater snail Biomphalaria alexandrina. Archives. Environmental. Contamination. Toxicology, 67: 192-202.

Finney, D. J., 1971. Probit Analysis. Cambridge University Press, Cambridge, London, $333 \mathrm{pp}$

Gazzy; A. A., Nadia M. Mostafa and Wafaa A. Shahawey. 2019. Survey, Population Dynamics and Estimation of Damage of Common Land Snail Species on Some Vegetable Plants and Egyptian clover at Some Regions at Kafr El-Sheikh Governorate. Journal Plant Protection and Pathology, Mansoura University, 10 (1):13-18.

IARC 2007. International Agency for Research on Cancer (IARC). Summaries and Evaluations-SILICA. 2 June.

Lu X., Y. Tian, Q. Zhao, T. Jin, S. Xiao, and X. Fan .2011. "Integrated metabonomics analysis of the size-response relationship of silica nanoparticles-induced toxicity in mice. Nanotechnology, 22 (5). Article ID 055101

Mohammed Gh. R. 2004. Ecological and biological studies on some species of snails. Master of Science. Agricultural. Sciences, Zagazig Univcity. 215 pages.

Mohammed Gh. R. 2018. Some laboratory studies on the efficacy of some plant extracts on biochemical and biological aspects of Monacha cartusiana land snail (Stylommatophora: Helicidae). Middle East Journal of Agriculture Research, 7, (4): 1867-1873. 
Noack, S. and CH. Reichmuth, 1978. Einrechnerisches Verfahren Zur Bestimmung Von beliebigen. Egyptian Journal. Agricultural. Research, 84 (5). 7.

Nykypanchuk D, Maye MM, van der Lelie D, Gang O.2008. DNA-guided crystallization of colloidal nanoparticles. Nature, 451: 549-552.

Pretty, J., Angus, C., Bain, M., Barton, J., Gladwell, V., Hine, R., Pilgrim, S., Cock, S.S. and Sellens, M. 2009. Nature, Childhood, Health and Life Pathways, Interdisciplinary Centre for Environment and Society Occasional Paper 2009-02. University of Essex, UK.

Raoofi, R.; Jahromi, H.K.; Jahromi, Z.K.; Abedi, H.A.; Sameni, H.and Pourahmad, M. (2016) Antioxidant effects of green-tea on biochemical and histopathological changes of liver in male rats poisoned by malathion insecticide. International Journal Medical Research Health Sciences, 5 (5), 361-370.

Sandra F. Gonc,Alves; Maria D. Pavlaki; Rafael Lopes; Julia Hammes; Julian Alberto Gallego-Urrea; Martin Hassellov; Kerstin Jurkschat; Alison Crossley and Susana Loureiroy 2017. Effects of Silver Nanoparticles on the Freshwater Snail Physa acuta: The Role of Test Media and Snails' Life Cycle Stage. Journal of Environmental Toxicology and Chemistry, 36(1): 243-253.

Safaa M. Ali; Naeima M. H. Yousef and Nivien A. Nafady. 2015. Application of Biosynthesized Silver Nanoparticles for the Control of Land Snail Eobania vermiculata and Some Plant Pathogenic Fungi. Journal of Nanomaterials, 10 pages.

Sana Besnaci; Samira Bensoltane; Fatma Moulka; Hadjira Braia; Labiba Zerari; Sihem Khadri and Hawa Loucif. 2016. Embryotoxicity evaluation of iron oxide $\mathrm{Fe} 2 \mathrm{O} 3$ on land snails: Helix aspersa. Journal of Entomology and Zoology Studies; 4(4): 317323.

Salunkhe, R. B., Patil, S.V., Patil, C. D. and Salunke, B. K. 2011. Larvicidal potential of silver nanoparticles synthesized using fungus Cochliobolus lunatus against Aedes aegypti (Linnaeus, 1762) and Anopheles stephensi Liston (Diptera; Culicidae). Parasitology. Research, 109: 823-831.

Sharaf, H.M., Abd El-Atti M.S. and Salama, M.A. 2015. Toxic effects of some pesticides on the enzymatic activities and spermatogenesis of the land snail Monacha cantiana. Journal of Bioscience and Applied Research, 1, (3): 139-146.

So, S. J., I. S. Jang, and C. S. Han .2008. "Effect of micro/nano silica particle feeding for mice. Journal of Nanoscience and Nanotechnology, 8 (10), 5367-5371.

Song Y. G., X. Li, and X. Q. Du. 2009. "Exposure to nanoparticles is related to pleural effusion, pulmonary fibrosis and granuloma. European Respiratory Journal, 34 (3), 559-567.

Steel, R; Torrie, J. and Dickey, D. 1997. Principles and procedures of Statistics: A Biometrical Approach, 3rd ed., McGraw-Hill, New York, NY.

Tiwari, D.K. and Behari, J. 2009. Biocidal nature of treatment of Ag-nanoparticle and ultrasonic irradiation in Escherichia coli dh5. Advances. Biology. Research, 3(3-4): 89-95.

Van der Zande, R. J. Vandebriel and M. J. Groot 2014. "Sub-chronic toxicity study in rats orally exposed to nanostructured silica.Particle and Fibre Toxicology, 11 (8).

Xiao-Ting Lu; Qiu-Yun Gu; Yanin Limpanont; Lan Gui Song; Zhong-Dao Wu; Kamolnetr Okanurak and Zhi-Yue Lv. 2018. Snail-borne parasitic diseases: an update on global epidemiological distribution transmission interruption and control methods. Infectious Diseases of Poverty, 7(28): 1-26.

Xie G., J. Sun, G. Zhon, L. Shi, and D. Zhan .2010. "Biodistribution and toxicity of intravenously administered silica nanoparticles in mice. Archives of Toxicology, 84 (3), 183-190. 
Ye Y., J. Liu, J. Xu, L. Sun, M. Chen, and M. Lan. 2010. "Nano-SiO2 induces apoptosis via activation of p53 and Bax mediated by oxidative stress in human hepatic cell line.Toxicology in Vitro, vol. 24 (3), 751-758.

Zhang. Q; L. Din; M. Li; W. Cui; W. Ding; J. Luo and Y. Zhang. 2013. Action modes of Aloe vera L. extracts against Tetranychus cinnabarinus Boisduval (Acarina: Tetranychidae). Agricultural. Sciences, 4(3): 117-122.

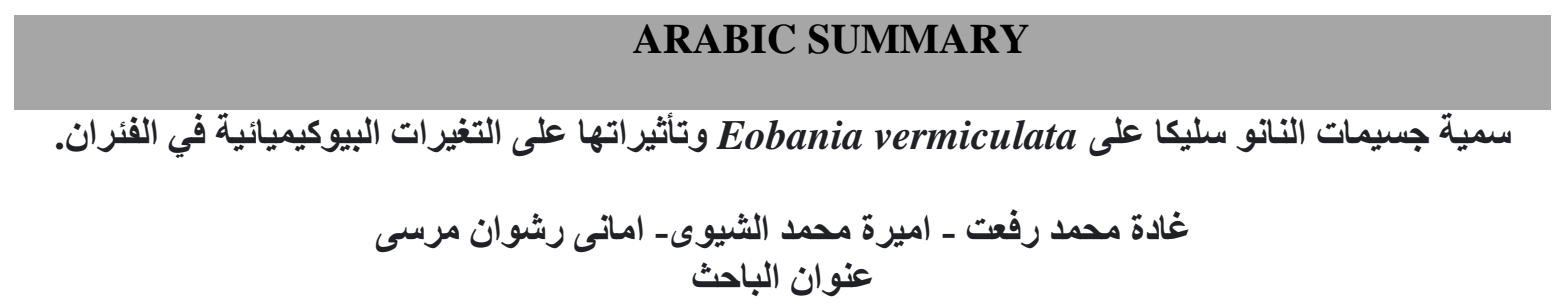

Correspondence author: amani.alzoheri@ fagr.bu.edu.eg

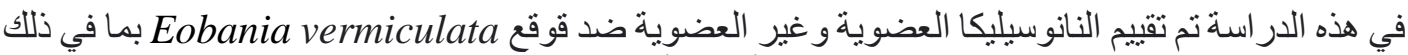

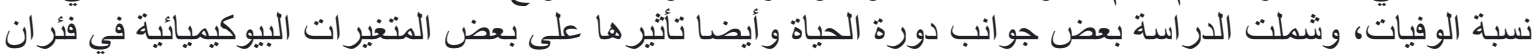
Albino Wistar

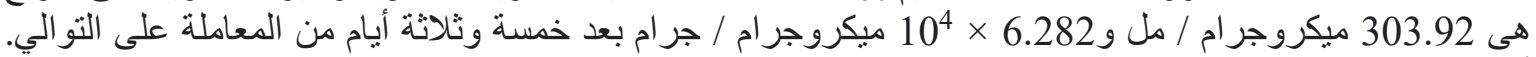

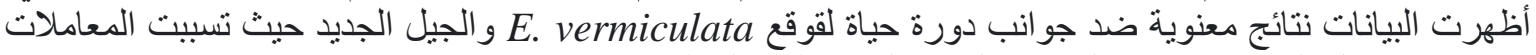
في خفض معدل التز اوج، وضع البيض و النسب المئوية لمرحلة اليرقة (50 و و 25) ،

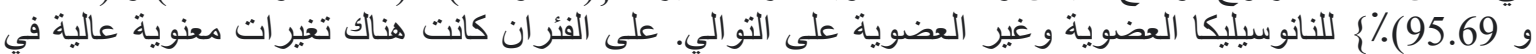

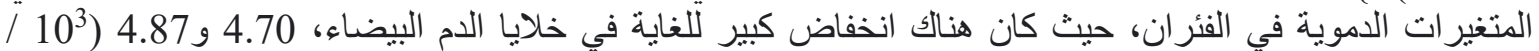

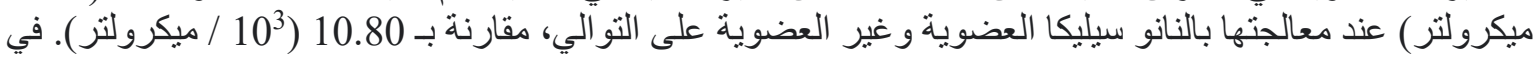

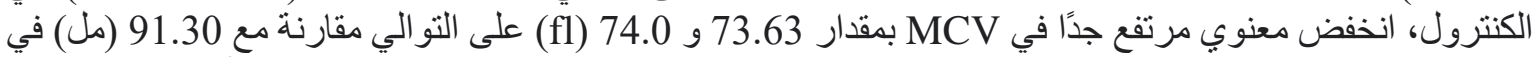

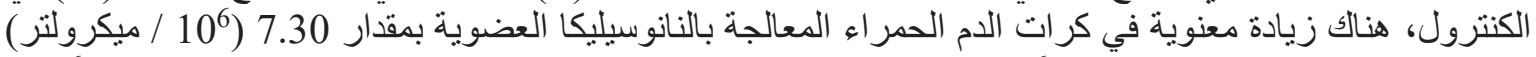

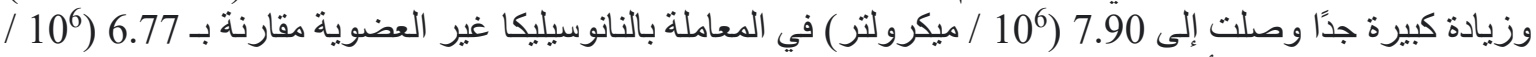

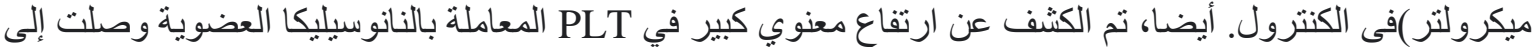

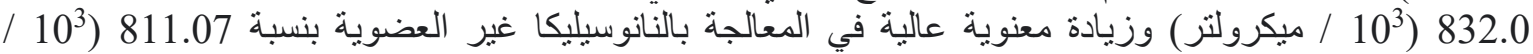

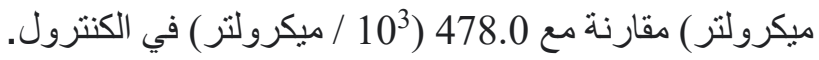

